\title{
The Model of Character Building Education Based on Islamic Boarding Campus
}

\author{
Muhammad Turhan Yani ${ }^{1}$, Slamet Setiawan², Agung Ari Subagyo ${ }^{3}$ \\ ${ }^{1}$ Faculty of Social Science and Law, Universitas Negeri Surabaya \\ ${ }^{2}$ Faculty of Languages and Arts, Universias Negeri Surabaya \\ ${ }^{3}$ Faculty of Languages and Arts, Universitas Negeri Surabaya \\ Email: ${ }^{1}$ muhammadturhan@unesa.ac.id, ${ }^{2}$ slametsetiawan@unesa.ac.id, ${ }^{3}$ agungari@unesa.ac.id
}

\begin{abstract}
The social pervasiveness of character-building education should be fiercely done for averting the deficiency of religion and nation values. There is evidence of the diminishing supreme moral values that can be witnessed from both printed and electronic media and even from the direct experience in society. Related to this, the implementation of supreme moral values is supposed to be effective through education. From that context, this study is regarded as important as one effort to integrate the academic realm with the supreme character values that are obtainable in a typical Islamic boarding campus. For the first year, this study purposes to (1) Observe the implementation of the character-building education in the State University of Surabaya (Unesa) and UIN Maliki Malang Islamic Boarding Campus; (2) setting up the draft of the model of the character building education based on Islamic boarding campus. In this study, the observation and interview are applied in collecting the data. The data is analyzed by creating the qualitative narrative about the application of the character building education in the State University of Surabaya (Unesa) and UIN Maliki Malang Ma'had/pesantren (Islamic boarding) Campus, followed by setting up the draft of the model of the character building education based on Islamic boarding campus. The results of this study are as follows: (1) the implementation of character building education in the State University of Surabaya (Unesa) and UIN Maliki Malang have their own trait and uniqueness; (2) the design of the model of the character building education has been arranged that can be used to be implemented in public campuses, such as Unesa.
\end{abstract}

Key terms: character building education, Islamic boarding campus

\section{INTRODUCTION}

The Indonesian education realm is often intimidated and blamed by the society's paradigm as the one most responsible for the failure of the implementation of character building. The Indonesian indigenous' character which is known as polite, harmonious, gotong royong (mutual cooperation), and prioritizing musyawarah (social deliberation) now is slowly wiped off by the advancing era. Concerning on that, the President reminds the society that character building education is now urgently needed to be applied and propagated. This idea was delivered by Mr. Susilo Bambang Yudhoyono in his speech in the moment of celebration of Hardiknas (the National Education Day) on May $11^{\text {th }} 2010$ in the State Palace. Moreover, the President confirmed, reflected from the highlighted news of Gayus's tax case, that the nation character building which has supreme moral behavior, budi pekerti (utmost nature), and ultimate manners is really important. The President also convinced that one way that can be accomplished is through education.

Furthermore, the Minister of Education and Culture of Indonesia, M. Nuh, firmly stated that nowadays the phenomenon of "sirkusitas" (acrobatic) has been extended in the society. More he explained that, "Phenomenon of sirkusitas is an indication of the diminishing of Indonesian society's original character which creates an anomaly that is ironicparadoxes and it has been our everyday phenomenon..." Outspokenly it is funny and mystifying to see the law forces that should be able to defend the law is found as guilty in charge instead. The national functionaries who should be able to serve society are found as the ones who asked to 
be spoiled and served. There are many other examples of the anomaly.

The President's and the Minister of Education and Culture's concern are expressed in entreaties and hopes. Mendikbud (Minister of Education and Culture) firmly stated that character building education is now being very important and basic in the effort to build the noble national character. That is the character of children of the nation who is able to give the best achievements which are envisioned by the truthfulness value. In addition, the President also expected to create nation's generation which has good personality, self-determining, self-esteem, high self-discipline, and many other good characters.

Vision of an education institution will determine how good the character building education will be implemented in the school's/campus' environments. Through the vision, the school/campus will present the real setting where the idealism and concrete vision of an individual will be the behavior's controller and the source of motivation up to the time when each individual in that institution grow well completely and fully (Aqib 2011:47). Here is where the prominence of education institution (campus) is needed to assist the employment of the character values through any way, any occurrence, also any supported situation and condition, for example through the existence of Islamic boarding campus.

According to the initial study that has been done by the observer team, the information that has been gathered is that there are some campuses that have already developed Islamic boarding in their education system. Mostly those are known as Islamic College; and one of them is Universitas Islam Negeri (UIN) Malang. While for public colleges, included Unesa, they still have not established the Islamic boarding within the education system but for only physical facility in the form of boarding building has existed in Unesa. The Islamic boarding that has been developed by UIN Malang is considered as effective in educating the students' characters. In the first year of college, students are obliged to live in the Islamic boarding campus to follow many guiding programs that have been set by the Islamic boarding campus (pesantren)/ Ma'had Aly Sunan Ampel UIN Maliki. The program includes character improvement. On the other hand, the character building education in Unesa is done through some activities such as extracurricular, includes in the subject, and the training of Bidikmisi students.

This study realizes that it is very important to expand the character building education through the Islamic boarding campus. This matter will be the special uniqueness in the context of "secular" campus because it will try to integrate the values in the Islamic boarding with the values of the secular campus. Furthermore, it will be design thoroughly for the model of character building education based on Islamic boarding campus as a unique model.

In connection with that, as an effort to answer the problem and to succeed the character building education in the campus, it is considered as prominent to create a development model of character building education by adopting the Islamic boarding. The model will be adapted further using the design that based on Islamic boarding. Therefore, this study is done to find the model of character building education in campus based on Islamic boarding campus. The result later can be useful as a reference for other public universities as a real effort to outspread the character building education.

In the context of this study, the implementation of character building education in both Unesa and UIN Maliki Malang will be explored more as a further and profounder determination. Then the model of the character building education based on the Islamic boarding will be described. The decription of the model is preceded by exploring the variants of the character building education's 
implementation in Unesa and UIN Malang. For the later stage, it will be formulated for a model of character building education which is based the campus according to the public campus/university, specifically in Unesa. The purposes of this study are (1) to explore the character building education in Unesa and Islamic boarding campus UIN Maliki Malang, and (2) to compile the design of the character building education based on the uniqueness of Islamic boarding campus.

\section{LITERATURE REVIEW}

Sigmund Freud in Aqib (2011:30) gives limitation that "Character is a striving system which underlies behavior." Character is a potential actualization from inside and internalization of the moral values which are from outside seems to be the part of one's personality. Character is the values that have been implanted in one's self through the education, pattern of child's upbringing, experience, trials, scarification, and environment's effect that has become the intrinsic value to motivate attitude and behavior. The character will be formed through simultaneous and consistent routine or customary.

While in character building education, according to Scerenke as quoted by Muchlas Samani and Hariyanto (2011:45) is considered as a sincere attempt where the positive feature of personalization is developed, encouraged, and manifested through the prototypical, study, and also emulation practice (the maximal effort to realize the wisdoms from everything that is learned and observed).

Furthermore, Samani and Hariyanto explain that character building education is a process of guidance giving to the learners to be a complete human who has the character in the dimension of heart, logic, body, also rasa dan karsa (feeling and intention). Character building education can be measured as the education of principles, the education of budi pekerti (utmost nature), the education of moral, and the education of nature which aim for developing the capability of the students to give the right-wrong judgment, to nurture the good matters, to realize that good matters in daily life with all of his heart.

The character's values that have been framed by Mendikbud consist of 18 characters that can be preference for schools in developing the character building education. Samani proposed that some basic characters that are prominently needed such as honest, trusted, self-control, hard working, appreciative, helpful, tough, and preserving (Samani 2012:6).

Character is close to the effectiveness, it takes quite much time and prototypical in its progress. Character is more likely built through the imitation process towards senior people who are respected rather than through the speeches. Considering that, in case of building the characters, parents and teachers should be able to be the role models. If every member in school such as the headmaster, the teachers, the administration staffs, and all of the employees can behave by applying the characters above, then the school will slowly form a strong capability to build students' good characters (Samani 2012:6).

Related to this, the forming of the students' characters actually should be not only applied in school/campus, but also demanding the important role of the family that cooperate well. The character (moral) education in school/campus is being the part of the character building education which is done by the family; as family is the informal institution education that later will be followed up by the school/campus (Yani 2007:15).

For Indonesian who agree to make Pancasila as the nation's philosophy and ideology. Character building education is a really important matter that can realize the nation's purpose to be Indonesian society completely. In this study, there is a term of manusia unggul (excellent human being) which is identified by being superior in many aspects such as in personality, in 
knowledge, and in creativity. Firm keIndonesiaan (Indonesian-like) character will be the main foundation to form and build the nation's identity, which later on can be the stable initial for the international social interaction. The character will create the daily behavior or in other words it will be the society's disposition (akhlak masyarakat) and the nation's disposition (akhlak bangsa). That becomes the reason why basically character building education is aimed for improving the Indonesian's supreme disposition (akhlak mulia) (Samani 2012:6). From the beginning the founder fathers had realized the importance of building the national character because without the honorable character, what it was aimed for building a nation will never be accomplished (Nurlaela 2011:32).

Nowadays, character building education becomes a serious problem among young generation across the world. The disappearance of respect towards parents and teachers, the pervasive of dishonest behavior, the occurrence of violent acts due to the lack of toleration to each other, free sex, also the drug addiction that makes teenagers become sloppy and fragile. In Indonesia, the fight among society group has become the common matter. Corruption cases in the daily news are no longer surprising. The people behavior in driving on the road mostly is able to describe people's character that wants to defeat others without giving consideration towards other persons' right. The saying "mencari orang pandai itu mudah, tetapi mencari orang jujur itu sulit" (to find person with brain is easy but to find person with earnest heart is difficult) becomes one example of how serious this national problem is (Samani 2011:vi). Those examples above remind us about how important the character building education's revitalization is. The awareness to come back to the education principle that is balancing heart, head, and hand also brings the awareness of basic of education which is humanizing human being (Samani 2011:vi)
In spite the fact that there are black and white human beings as proposed by Caesare Lambrosso, it is impossible to deny the importance of education. In different capacity, education is needed by everybody, both by persons with bad character basic and by persons with good character basic. The cohesion between ajar dan dasar (teaching and basic) that was preserved by $\mathrm{Ki}$ Hajar Dewantara, is the reflection of the fact that education is impossible to be denied (Darma 2011:xiv). Ajar is the education while dasar is basic of human being that is embedded to each person since the birth.

Various national elements express their comments and worries that nowadays, national society is lack in showing the virtuous attitude in being the part of society, nation, and country. It indicates there is something gone and banished in this nation. The act of permitting any ways to get the destination for individual or group matter can easily be found in the daily life. What is wrong with this nation? Reacting to that kind of social cultural phenomenon, many opinions have appeared on the surface; for example an opinion that expresses that this nation has been uprooted from the cultural root, that this nation has affected by the globalizing democracy and democratizing globalization, and that this nation has gone crazy along the people (Sutarto 2011:11).

Merle J. Schwartts (2007) in his book entitled "Effective Character Building Education" as quoted by Samani (2011:v) explained that character development is about developing virtues good habits and dispositions that lead students to responsible and mature adulthood. That is why, Ki Hajar Dewantara who is known as the father of Indonesian education reminded others that education is one way to develop the character potential, intellectual, and figure fully to create a perfect individual (Samani 2011:v).

Advanced and innovative nation will not be created only by the competence, advanced technologies, as well as the nature productivity, but it is created by the 
spirit of the national character instead. It is proved and shown by some countries such as Japan, South Korean, China, and England. The character's role for an individual is similar to the role of the driving wheel for a ship. Character is a life's wheel that will determine the right direction in undergoing each individual's life (Aqib 2011:40). Furthermore Aqib stated that in character developing at least there are four corridors that are needed to be done, there are (a) integrating the values, (b) distinguishing which one is allowed and which one is not, (c) forming the habitual action, and (d) being the exemplary or model as an individual with good character.

UU No. 20 in 2003 about Sisdiknas (The System of National Education) Verse 3 stated that the national education aims for developing the abilities and building the character and the civilization of honorable nation due to educate the nation living which aims for being a human being who has faith and keeps faith to the God Almighty, has noble disposition, healthy, educated, creative, independent, also to be democratic and responsible citizen (Aqib 2011:40).

The platform of Indonesian's character building education has being proposed and initiated by the important figure of national education named $\mathrm{Ki}$ Hajar Dewantara which is expressed in his three famous sentences; Ing ngarsa sung tuladha (in front of giving example), Ing madya mangun karsa (in the middle establishing the idea), Tut wuri handayani (from behind giving the encouragement). According to Aqib, the vision of character building education which is applied by schools is the goal that should be accomplished through the effort of institution of education. Without the vision which is expressed within the clear statement that is understood by every party involved in that institution, the development of the character building education will be inadequate (Aqib 2011:45).
The vision of one institution of education determines how far the program of the character building education will be successful to be applied in the school (campus) environment. Using this vision, the school (campus) gives a real situation where the idealism and the desire will concretely be the orientation to behave, the source of motivation so that the individual in an institution can be developed fully and completely (Aqib 2011:47)

We are deserved to be happy for there are many school that have been already successful in developing the character building education under various names of the institution. Thorough observation towards those schools have resulted that character building education does not need luxury facilities, it only needs acclimatization which is then followed by the implementation of the values that will lead to the acculturation. That process should be done consistently and escorted with the prototypical (Samani 2012:x).

Various studies have shown that globalization era with the tight competition is really determined by the human resources. Countries with the reliable and strong human resources will be able to use every chance in every competition (Samani 2012:5). The World Bank's study towards 150 countries shows that the country's advance is determined by the innovation (45\%), networking (25\%), technology $(20 \%)$, and natural resources $(10 \%)$. The first three factor-innovation, networking, technology-are the part of human resources and only $10 \%$ excludes that (Samani 2012:5).

Based on the explanation above, education is the main foundation to develop the human resources to provide Indonesia to be involved and to take part in the global era. Education should be capable in improving two basic aspects which are character and competence as the essential need in the competition which grows tighter (Samani 2012:5). Those two aspects are a whole unit that should be possessed by Indonesia. In order to accomplish that, the 
educators should consciously work on those two aspects through the education (Samani 2012:5-6).

The rapid advancement of technology along line with the spirit of global trend causes the inevitable change in lifestyle. Worse, it threatens the local customs. Local customs are nowadays being pushed away even uprooted from the communities (Setiawan 2012:1). In order to deal with that kind of situation then it is really necessary to protect our nation by strengthening the national character through the education and one effective way is by designing the education system based Islamic boarding campus.

Islamic boarding campuses are still rarely to be found in Indonesia. There are only few universities which apply the Islamic boarding campus, like UIN Maliki Malang. The function of boarding building in some other universities is rather educative and not really concerning to the religion aspect. The term "campus" is more likely familiar as a place to study academic subjects and to prioritize the intellectual side while the spiritual side has not been totally the main program in the campus' living. On the other hand, Islamic boarding is famously recognized as a place to expand the spiritual side instead of the intellectual side. If those two aspects are integrated, the concept of Islamic boarding campus will be an attempt to unite the values in the Islamic boarding to be adopted into the campus concept in the perspective of character building education.

Related to this, it is significant to mention the previous study by Miftahul Huda (2006). The result can be stated that, from its existence, the boarding system in Indonesia can be categorized into three groups. The first one is the boarding house which is functioned as the place for the college students with academic achievements to stay. The activities in this type of boarding place are the activities which are programmed by the inhabitants so that the activities indicate the distinguished impression from the university. Secondly, the type of boarding house that accommodates the living place for the activist/affiliations of intra and extra campus organization. The activities in this kind of boarding system are mostly related to the organization's routines which usually do not get the control from the university. The third type is the student's boarding that is built for students who want to stay there without any specific requirements (as in Unesa). The activities in this type of boarding house cannot be really managed well. According to those three types of boarding house, UIN Maliki Malang has improved the campus Ma'had (Islamic boarding) as an attempt to realize its work programs integrally and systematically along the campus' vision and missions. The result shows that there is incredible improvement for especially the character buildings and other competences for the students after being educated and trained in the Islamic boarding within a year.

\section{RESEARCH METHOD}

This study is a development research which is initiated by the observation and interviews regarding the application of the character building education in a public university (Unesa) and Islamic boarding campus UIN Malang. This study is expected to be able to formulate and develop an inspiring model of character building education based on the Islamic boarding campus. There are some stages to gather the data and to do development research in this study which apply interview, observation, and focus group discussion. In detail, the design of this study is as follow.

The first year action is to observe the application of the character building education both in Unesa and in Islamic boarding campus UIN Maliki Malang and to design the draft of the model of the character building education based on the Islamic boarding campus. After that, the data are analyzed by using the qualitative narrative and the focus group discussion 
(FGD) techniques. For clearer description, the design can be seen in the following table.

Research Design

\begin{tabular}{|c|c|c|c|c|}
\hline No & KEGIATAN & TUJUAN & METODE & HASIL \\
\hline & \multirow[t]{2}{*}{$\begin{array}{l}\text { - Mapping } \\
\text { - Model } \\
\text { Planning }\end{array}$} & $\begin{array}{l}\text { Getting a picture } \\
\text { of the application } \\
\text { of character } \\
\text { building } \\
\text { education in } \\
\text { Unesa and UIN } \\
\text { Maliki Malang. }\end{array}$ & $\begin{array}{l}\text { - Observatio } \\
\mathrm{n} \quad \text { and } \\
\text { interview }\end{array}$ & $\begin{array}{l}\text { - The information are } \\
\text { gathered through the } \\
\text { obswervation and } \\
\text { interview regarding the } \\
\text { application of character } \\
\text { building education in } \\
\text { Unesa and UIN Maliki } \\
\text { Malang. }\end{array}$ \\
\hline & & $\begin{array}{l}\text { Designing the } \\
\text { model of the } \\
\text { character } \\
\text { building } \\
\text { education based } \\
\text { on Islamic } \\
\text { boarding } \\
\text { campus. }\end{array}$ & $\begin{array}{l}\text { - Focus } \\
\text { Group } \\
\text { Discussion }\end{array}$ & $\begin{array}{l}\text { - The model of the character } \\
\text { building education based } \\
\text { on Islamic boarding } \\
\text { campus has been designed. }\end{array}$ \\
\hline
\end{tabular}

Research Roadmap

\begin{tabular}{|c|}
\hline Research \\
Problems \\
\hline How is the application of \\
character building \\
education in Unesa and \\
Islamic boarding campus \\
(pesantren) UIN Maliki \\
Malang? How is the \\
model of the character \\
building education \\
based on Islamic \\
boarding campus \\
(pesantren)?
\end{tabular}

The setting of the development of the character building education based on the Islamic boarding campus is expected to contribute to pervasive the character values to the campus academic members (especially the college students). The concept of Islamic boarding that is embedded to the campus possesses uniqueness that is different from the common concept of Islamic boarding and is

\begin{tabular}{|l||l|}
\hline \multicolumn{1}{|c|}{\begin{tabular}{|l|} 
Research \\
Outline
\end{tabular}} & $\begin{array}{l}\text { Indicator of } \\
\text { Completion }\end{array}$ \\
\hline $\begin{array}{l}\text { The design of the } \\
\text { model of the } \\
\text { character } \\
\text { building } \\
\text { education based } \\
\text { on Islamic } \\
\text { boarding } \\
\text { campus. }\end{array}$ & $\begin{array}{l}\text { The information } \\
\text { regarding the } \\
\text { application of the } \\
\text { character building } \\
\text { education in Unesa } \\
\text { and UIN Malang has } \\
\text { been gathered, } \\
\text { andther model of the } \\
\text { character building } \\
\text { education based on } \\
\text { Islamic boarding } \\
\text { campus has been } \\
\text { designed }\end{array}$ \\
\hline
\end{tabular}

also different from the common concept of the campus. Thus, there will be a typical uniqueness in the development of the character building education in campus.

In connection with that, in the context of this study, it is important to develop the Islamic boarding in public/secular campus with the design of the character building education based on the Islamic boarding campus. This will be a 
unique in the context of secular campus which tries to integrate the values which is in the Islamic boarding and in the secular campus. Then it will be designed thoroughly for the model of the character building education based on Islamic boarding as the exceptional model.
The position of this research to improve the character building education in the unique way that is character building education based on Islamic boarding campus is represented in the research mapping below.

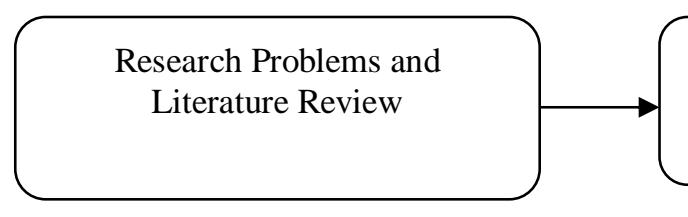

\section{RESULT AND DISCUSSION}

\section{RESULT}

A. The Implementation of the Character Building Education

This section covers two sections, namely: first, the description of the application of Character building education in UNESA and the scond section is the description of the application of Character building education in UIN Maliki Malang.

1. The Application of the Character building education in UNESA (State University of Surabaya)

Growing with Character is a sentence that is the slogan of Unesa since 2010. That slogan obliges Unesa to assist the implementation and the preservation of the character values through any activities. The character building education in Unesa is implemented through some strategies such as subject program (there are subjects of character building education in PPKn (the Education of Pancasila and Civics subjects $\}$ in the Social Science Faculty (FIS), character habituation (self-discipline and honesty canteen), and using the extracurricular activities for the students.

The implementation of the character building education through the subject program, either by making it as particular subject or by inserting it to all the subjects, is expected to strengthen and to emphasize that every subject carries the spirit of the realization of the process. The result of education result is able to create an individual with the supreme character. That

\section{Data Collecting \\ Methodand Analysis \\ Verification of the Model of the \\ Character building education Based on the Campus Islamic Boarding}

kind of spirit is one of the realizations of the Unesa motto as a convincing campus through a slogan: Growing with Character. In addition, the implementation of the character building education through the acclimatization in Unesa can be seen from many aspects such as preserving the green campus environment, maintaining the conducive facilities to create academic atmosphere, providing some honesty canteens in some faculties, requiring the students' disciplinary in wearing the jacket during the final examination, and being discipline in the study and reporting the result of the students' study by the lecturers.

On the other hand, the implementation of the character building education through the extracurricular aims for students both Bidikmisi and non Bidikmisi, and also the student organization's functionalists in Unesa. The activities involve the students' character improvement especially emphasizing some characters such as discipline, independent, and responsible. Some activities are executed in cooperation with a team from Kodikmar AL (Navy Seal). There is also an activity to build the leadership character named LKMMTD (The Basic Leadership Training for College Students) and LKTM (The continuity of LKMMTD). For students of the year 2012, the activity has been improved by adding the training to develop students' entrepreneurship to prepare them to to be able to live independently and to have the sense of entrepreneurship. This idea is regarded to 
be prominent for Bidikmisi students to cut off the chain of poverty.

Intended for the Bidikmisi students in Unesa, the discipline character is built by requiring them to join the flag ceremony in every national special day. They are also required to join the character training program to be independent student. That kind of character is regarded as important to be possessed by the students in order to achieve the better life quality in their future for themselves, their family, their society, also their nation and country in general.

Aimed for those who are active in student organization (Ormawa), Unesa also prepares the Kader Bangsa (national leader's generation) activity. Each student organization and extracurricular (UKM) in Unesa is required to send 3 to 5 activists to be representative in this activity. They get the training and the guidance from Dikti team to be Kader Bangsa (national leader's generation) who will be always ready in helping to solve problems that occur in society. After getting the materials, they will be located to some areas that face problems and demand solution. One example is in Tretes, Pasuruan, the society there face a social problem. The social environment is not conducive because there is an area of prostitution. Here, Unesa students are demanded to give the solution to the society. Another example is to face the group of people who is demanding something to the government through the demonstration. Unesa students are expected to be able to hold the crowd by discussing the problems carefully and objectively.

The religious character has also been culture in the students' environs through one program named Ta'limu Qiraatil Quran (TQQ). TQQ is a religious activity in Unesa that is technically handled by the lecturer team of Islam Education which is also helped by students from UKKI (Unit of Islamic Religious Activity) Unesa. During the study in Unesa, every moslem student is obliged to follow this activity for one whole semester. This activity has been the curricular of Islam Education subject which was started in 1988 and is in progress until now.

Generally, Unesa students indicate to having good character, but only sometimes there are some students who cannot really save the Unesa's reputation. According to the PR 3 Unesa (the Deputy Rector for Student Affairs), Mr. Warsono, this situation is similar to Indonesian saying Nila satu titik merusak susu sebelanga (Because of one spot of stain, a pot of milk will be ruined). That kind of reality is also seen in the dispute of the election of the leader of Ormawa (not in all Ormawa) in Unesa either in the level of department or in the level of faculty (as happened in Social Faculty), that sometimes they cannot indicate the good character because they create the gap between groups which usually make the situation becomes worse even lead to the physical quarrel. This matter becomes everybody's concern especially by the PR 3 of Unesa and PD 3 (the Deputy Dean for Student Affairs), particularly, of Social Science Faculty (FIS) Unesa.

As the head of the student section, the Deputy Rector for Student Affairs often gives advices to the students. He even often tells them that being involved in organization is for building students' network not for defeating each other. As it is compared, more colour in Pelangi (rainbow) will give students more advantages, especially by the time the students graduate, they will be able to help each other. According to PR 3 (the Deputy Rector for Student Affairs) of Unesa, the students' construction that is related to the election that brings the benefits of each Ormek (the student organization outside campus) should be mended so it will not create the high tense among the Ormek like PMII, HMI, IMM or GMNI. It will be better for them to cooperate so that Pelangi can be accomplished.

On the otherhand, PD 3 (the Deputy Dean for Student Affairs) in Unesa Social Science Faculty, Anik Andayani 
who has been facing the difficulties in handling Ormawa in FIS in this two years feels sorry for the students are still not capable to show the character that has been purposed by Unesa through its slogan Growing With Character. This is what Anik Andayani feels as long as she is positioned as PD 3 (the Deputy Dean for Student Affairs) in Unesa Social Science Faculty. One time of her period as PD 3 (the Deputy Dean for Student Affairs) in Unesa Social Science Faculty, in 2013, Ormawa in FIS (Social Science Faculty) was grounded because the students were being polarized into groups that cannot be compromised with one another. In 2014, the Ormawa (student organization)had their suspended period for a few months after the Faculty Election for the leader of Ormawa (student organization). This is also because the students were polarized into different groups that cannot accept the result of the election. The mediation way had been through for putting the opposition groups together but it was still difficult to get the expected outcome.

According to PD 3 (the Deputy Dean for Student Affairs) in Unesa Social Science Faculty, the Unesa's slogan which emphasizes to the character building is still not able to inspire most of the students especially for those who are active in student organization to be really applied in the form of democracy in the campus. One example is in the election event to choose the Leader and the Vice Leader of the BEM (Student Board Organization) in Unesa Social Science Faculty. In her opinion, this is a difficult challenge for her section and also for the students in general.

The habituation of character, according to PR 3 (the Deputy Rector for Student Affairs) of Unesa, can also be covered through the activities that are held by the UKM. According to him, UKM is a place for students with the same interest and talents, they then gather to design some activities that show their talents. For example, those who are interested in the religion can be united in
UKM-UKKI, those with interest and talent that is related to the scientific can join UKM-UKIM, those who are interested and talented in arts can be provided in UKMSeni (Art), those who have interest and talent in sports can join UKMKeolahragaan (Sport), and many others. Unfortunately, Unesa has not really given the chance for the students to express and show their talents and interests at campus. UKM should have been planning the routine agenda for the students who want to express their talents at campus everyday that can also enlighten the campus life.

For preserving Unesa from bad reputation, Unesa's PR 3 (the Deputy Rector for Student Affairs) will decide a policy that will prohibit students to have any activity at campus after $10 \mathrm{pm}$ and he also plans to maximize the role of the campus security. Besides that, he will try to provide campus with the proper lights that will help the security to keep their eyes on the students' activities at night because there is worriedness that campus will be used for improper activities such as making out, drug transaction, and many others.

On the other hand, the implementation of character building education in Unesa is also being strengthened by placing students in Boarding Campus, as in Unesa Lidah Wetan Campus which facilitates freshmen to live in Boarding Campus. But as Unesa Leader's policy, fresh students are not obliged to live in Boarding Campus, since the Boarding Campus facility is also not enough to accommodate all freshmen. So far, the capacity of Boarding Campus is one building for is 300 students.

Boarding Campus facility that has settled also is not fulfilled by students; it is only 200 students out of 300 students' capacity. According to Utami SE and Elis, Boarding Campus' person in charge, it is because less information to give about this Boarding Campus to freshmen and their parents. Since Boarding House has operated since 2010, it is always not fulfilled anyway. However, if it is 
compared to the facilities outside the campus (other boarding houses), Boarding Campus is not worse than them, especially if it is compared to the plus mark in it, such as religion founding, social founding, and competency founding. It does have the plus mark.

Based on the data that collected by the researchers, Unesa Boarding Campus has done character building for students. Unfortunately it is not really maximal in its realization. Character building here consists of religious character, caring character, and competent character. The representation of religious character is, Boarding Campus has planned religion activities once a week to do Yasinan . Unfortunately, in its application, it is only carried out once a month, even once every three months. This is what we feel less maximal to do. Beside that there are also some plans for every Religion Important Day.

For caring character, Boarding Campus has planned Social Loyalty to Orphanage and Orphans by sending some students to some orphanages to give their hand to orphanages or invite the orphans to Boarding Campus. Caring character like this is important to be had by students as representation as social creature.

While for Competent character, Boarding Campus has supported students to reuse the garbage by separating it into dry garbage and wet garbage, for the next these will be reused for handicraft (for dry garbage). According to the organizer of Boarding Campus, this competent character needs to be applied so that the students can learn how to catch the opportunity.

Character building in Boarding Campus doesn't look like fully having synergy with another campus programs. Between campus programs and Boarding Campus programs, they do not show any relation yet, or in the other words, the activities that have planned in Boarding Campus did not relate to activities by Unesa, as it is the other way. In fact, because it is one property of Unesa, the activities should be related to them, so that it does not look like that Boarding Campus is only used to accommodate student living, but also there are optimum educative functions in it for better students'character building.

In terms of management, Unesa Boarding Campus also does not show a good synergy yet between Girls Boarding Campus with PGSD Boarding Campus, because each of them is managed in different way. For instance Boarding Campus is special to accommodate girl students with more strict rules, while PGSD boarding accommodates boy-girl students in the same building, but separate rooms. It surely opens the possibilities to improper activities happen, such as too free intercourse because of the close rooms, etc.

Outside Boarding Campus which is facilitated legally by campus, there are also some boarding houses which are managed by some Unesa students (boys or girls) who gathered in the same student organization, such as AlMufidah, Alkayyis, Albatul, etc. Those boarding houses have used the same facilities like general, even closely to pesantren system, which inside it also works the educative function and learning, such as religious activities schedule, discussion, etc.

2. The Application of Character Building Education in UIN-Malang Based on Ma'had (Campus Pesantren/Islamic Boarding Campus)

"Depth in Spiritual, Glory in Character, Strength in Knowledge, and Maturity in Profession" is the slogan of UIN Maliki Malang to motivate their civitas academica (all members of academy). Character Building Education in UIN Maliki Malang which is based on Islamic Boarding Campus has been done through many kind of activities which reflect culture and refraction for students who are also Ma'had students. The character cultivation in students daily life is emphasized on character building aspect including religious, responsible, discipline, 
tawadlu', live together, charitable, and competitive.

The emphasizing of religious aspect in Ma'had is the priority to produce graduates to be Alim who is Ulama and Ulama which is Alim. Religious characters are showed in students' activities, especially when they are in Ma'had. So many kinds of religious activities that have been followed by them as Ma'had has planned before, such as reading Al-Quran, reading shalawat, istighasah, reading yasin, taklim (analyze religion literature book), religion discussion, etc.

It is also for ibadah habit as the representation of religiosity. Students very appreciate this, for instance, five times jama'ah prayers, tahajud prayer, and Monday and Thursday fasting. Students usually wake up before Subuh around 3 a.m. to get ready for all the routine activities until 7.30 a.m. These activities make them enjoy doing the habitual as if religious character has united in their life. According to Ma'had Director, Mr. Israqunnajah who are called as Gus Is, parents usually give the feedback information about their children's ibadah habit in Ma'had has affected their family when they are in home.

This thing shows that religious character has been cultivated inside students' personality when they are in Ma'had and Campus. It brings positive effects and good spirit for family in ibadah refraction. Parents that usually do not do the ibadah routine such as jamaah prayer and tahajud prayer, they become motivated to follow the activity because their children not only reminding but also inviting the parents to follow their habit in Ma'had. Parents are grateful because their children bring a change to religion life which becomes more religious in their family.

The emphasizing of religious aspect is a refraction which is cultivation around Ma'had students. On the early period before they join Ma'had, they are not common with those activities like in Ma'had, but after they live in Ma'had finally they are able to adapt the activities that are planned by $M a^{\prime} h a d$. Now they start to enjoy and to get used to doing the activities. Furthermore, they commonly do the activities even though they do not live in Ma'had any longer.

The representation of character building education in UIN Malang is also developed through Uswatun Hasanah (providing a good model). The model is given byMudir (caretaker), Murabbi (Advisor), and Musrif/Musyrifah (CoAdvisor). This way is good effective impact for students. Providing a good model means that the advisors have given a good example when they are preparing themselves before doingMa'had activities. Advisor wake up earlier than students to do tahajud prayer, speak and act politely. In speaking, advisors give example to speak politely and say salam first when they meet the students. These also can motivate students to adapt it.

The representation of character building education is also developed with emphasizing the discipline founding, such as students come on time on Ma'had activities, and for those who are late will be punished by educative punishment, for instance to memorize surah-surah in juz 30.

The representation of character building education in Ma'had also emphasizes to responsible character, for instance every student is obligated to khatam (finish reading the whole Quran) in a year in Ma'had. To facilitate this program, ma'had and campus prepare 40 hafidzhafidzah who always standby every day in campus' mosque and in buildings to receive Al-Quran memorizing from students every time. With this program students have responsibility to khatam the Quran. As long they do not finish it yet, they cannot graduate from Ma'had because khatam Quran is an obligate requirement for UIN to graduate from Ma'had and exam comprehensive requirement before thesis. Even the responsibility to fluently read AlQuran is also prevailed for lecturer and administration staff soon to be. When they has passed CPNS test in UIN, they must be 
able to read Quran. The lecturer/administration staff's decree will be given to them after they can read AlQuran well.

Students who do not graduate yet as equal as Ma'had's parameter, such as khatam Al Quran, Do not pass Ma'had's final examination (akhirussanah), they also cannot take subjects related to religion (Quran Analysis, Hadist Anaylisis, Fiqih Analysis, Tasawuf Analysis, and many others). Because Ma'had program and campus are connected to each other by the online system, students must finish their graduation first on $M a^{\prime} h a d$ then they can take religion subjects. The policy is required for all major programs in UIN, either religion or general major.

For those who cannot fulfill the graduation standard from $M a^{\prime} h a d$ at the end of the year (akhirussanah), they will be given a remedial. This is expected that the students can graduate from Ma'had soon and can take subjects on campus at the following semester. This means that Ma'had program is related to, even integrated to campus program, on Major level, department, faculty, or university. All of them are based on computerized system or online.

For UIN students on their first year on campus, they have to stay in Ma'had which can accommodate around 3500 students every year. They are trained through many kinds of Ma'had programs, such as character building in all aspects, foreign language affirmation (ArabicEnglish), and many others. For students on the first year, campus has scheduled the lecture from 8 a.m., because starting from Subuh up to 7 a.m. they still follow the activity on Ma'had. Campus is not allowed to schedule the lecture before 8 a.m.

Responsible character building is showed on a target that Ma'had students must be capable in foreign languages (Arabic-English). To achieve those programs, there is an intensive course by using Arabic-English language which is called as MKPBA-MKPBI (Mata Kuliah
Pendidikan Bahasa Arab/Inggris) for 9 credits; these activities are held on Monday-Friday at 2 - 8 p.m.

On the other hand, tawadlu' character has used to students in Ma'had environment, for instance students always say salam with bowing their head when they meet advisors/lecturer on their way to class. It has been cultivated around Ma'had students when calling Musyrif/Musyrifah (Co-Advisor Boy/Girl) who are their seniors as ustadz/ustadzah. This Tawadlu' shows a 'down to earth' attitude from students as their respect to their advisors. Even an orator student can show tawadlu attitude when he/she meets and talks to the lecturer.

UIN is also developed through extracurricular activities. This strategy is developed for all departments/major, which are covered under the name of akhlaqtasawuf education which consists of 2 credits, beside Quran Analysis, Hadist Analysis, Fiqih Analysis for all departments, general or religious, the students should khatam AlQuran as the requirements of comprehensive examination.

The representation of character building education also emphasizes togetherness character, which students are cultivated to live together in harmony with others, without seeing social background, race, hometown, etc. They have been placed and grouped randomly by Ma'had. That is why students cannot choose their own members by themselves. As in Ma'had for a year, they can interact well. There is a case, where a student that has been placed on the same room by the friends who previously had problem in their Senior High School, but after they are gathered on the same room in UIN they can live in harmony.

The character building education also is implanted through caring character under the name generous character. In every building is placed a 'kotak amal' (a charity box) which has purpose: students 
habitually give their money for charity, for instance: put Rp 1000, Rp 2.000, or even more into the charity box in every Mabna (building). For the result, money from the boxes then will be used for helping poor UIN students.

For lecturers and staffs, they are also trained to be generous with $2.5 \%$ zakat from their monthly salary that will be managed by Badan Amil Zakat which is managed by UIN, later it will be distributed especially to poor students and other planned purposes.

The practice of character building education also focuses on competitive character. Every Mabna (Ma'had building) which consists of nine buildings, and every building has one caretaker who is helped by some Murabbi (Advisor) and Musyrif (CoAdvisor) will hold some competitions which are joined by all students from all Mabna. The branches of competition that are routinely held by all Mabna regularly, such as: nadhom (poem); foreign languages competition (Arabic-English); religious music competition with instruments like rebana,etc; Future Dai competition, etc.

\section{DISCUSSION}

The implementation of character building education in Unesa and UIN Maliki Malang has been executed with unique variations. It is not only on formal education in the class, but also on wider area through attitude cultivation and habitual. This matter can be understood since the character is more likely to affect affective aspect and attitude rather than cognitive aspect.

According to Muchlas Samani, character is close to the effectiveness, it takes quite much time and prototypical in its progress. Character is more likely built through the imitation process towards senior people who are respected rather than through the speeches. Considering to this, in case of building the characters, pare nts and teachers should be able to be the role models. If every member in school such as the headmaster, the teachers, the administration staffs, and all of the employees can behave by applying the characters above, then the school will slowly form a strong capability to build students' good characters (Samani 2012:6).

Related to this, the forming of the students' characters should be not only applied in school/campus, but also demanding the important role of the family that cooperate well. The character (moral) education in school/campus is being the part of the character building education which is done by the family as this is the informal institution education that later will be followed up by the school/campus (Yani 2007:15).

According to Yudi Latif, a nation observer (2014), education has a duty to form tolerant generation, well behaved, and loving. Education also should dig various potentials of the nation and grow a pride for the nation. Moreover, in his opinion, education is cultivation process and creation of cultural human. The platform of Indonesian's character building education has being proposed and initiated by the important figure of national education, $\mathrm{Ki}$ Hajar Dewantara, which is expressed in his three famous sentences; Ing ngarsa sung tuladha (in front of giving example), Ing madya mangun karsa (from the middle establishing the idea), Tut wuri handayani (from behind giving the encouragement). According to Aqib, the vision of character building education which is applied by schools is the goal that should be accomplished through the effort of institution of education. Without vision which is expressed within the clear statement that is understood by every party involved in that institution, the development of the character building education will be inadequate (Aqib 2011:45).

Related to vision-mission from campus for the effective success in character building, one of them is by designing an Islamic boarding campus as character building through cultivation in 
students life, also carry out a lot of activities to grow another positive characters, such as religious character, discipline character, responsible character, strength character, live together character.

If we analyze theoretically, there are some implementation models of character building education. According to Husein et al. (2010), there are monolithic model, integration model, outside class teaching model, and compilation model. The implementation of character building education in Unesa includes to monolithic model, integration model, and outside class teaching model. Furthermore according to Husein et al. (2010), monolithic model is understood as independent model, it is character building education as a subject to other subjects. The advantage of this model is the material that is more measurable. While the weakness of this model depends on curriculum demands. The application of moral character seems to be the responsibility of one lecturer,. Furthermore, the effect only touches cognitive aspect, without touching the internal process (Husein et al. $2010: 30-31$ ). This monolithic model exists in PPKn subject in Social Science Faculty-Unesa, but it does not exist on other departments. But, even though the implementation of character building education in Unesa applies monolithic model, in the realization, internal process and habitual attitude of students become main part of the teaching.

Beside monolithic model, the integration model is implemented in Unesa. Integration model, according to Washington et al. as in Husein et al. (2010), purposes that character building education is integrated into other majors. On this context, all lecturers are responsible for applying the character building education to students by choosing the topic that character value can be inserted.

The implementation of character building education in Unesa is also included into the outside class teaching model. This model can be seen from programs that are planned by the section of
Student Affairs, particularly for Bidikmisi students, which consist of character building education program, entrepreneurship developing program for independent character, leadership training program to found strong character, etc.

While the implementation of character building education in UIN Maliki Malang, are not only monolithic model, integration model, and outside class teaching model, but also compilation model. Compilation model combines all models together with others to participate the conservation of character morals cultivation in personality of each students through Islamic boarding campus. The effective effort on character building education implementation beside monolithic model, integration model, and outside class teaching model, it needs compilation model, in which the Islamic boarding campus can accommodate those all models.

Integration and compilation model also give more advantages if compared to monolithic model, the integration and compilation model in UIN Malang. This means that all programs planned by campus are based on Ma'had recommendation (Islamic CampusBoarding House). For instance, Ma'had recommends certain students who have not graduated from Ma'had (because have not finished the assignments or because of having bad attitude), to be banned to follow campus programs. This rule also exists for those who do not finish $M a^{\prime} h a d$ material. Thus, those students cannot take religious subjects on major curriculum structure. The system between Campus and Ma'had is done by online so the students cannot manipulate the data.

After elaborating the implementation of character building education in Unesa and UIN Maliki Malang, it is found that each of them has their own characteristic. Unesa as public campus has emphasized as campus with mission to realize positive characters for academicians with slogan "Growing with 
character". While UIN Maliki Malang religious campus and also Islamic boarding campus is with mission in a slogan: Depth in Spiritual, Glory in Character, Strength in Knowledge, and Maturity in Profession". Each university has committed to create a glorious character personal, which is not only concern to academic developing.

Seeing what Unesa and UIN Malang have done, this research journal will design character building education model based on Islamic boarding campus. Unesa as public university surely cannot adopt the whole system of UIN Malang directly as Islamic boarding campus. However, Unesa with existed facility
(Boarding Campus ) can design a character building education model which is based on Islamic boarding campus by looking for the similarity of UIN Malang, even though it is not integrated fully with campus programs like what UIN Malang does. The following is a model of the character building education based on Islamic boarding campus which can be implemented in Unesa.

Main Target

Unesa

Bidikmisi Students

Boarding Campus Facility : 2 Buildings (1 Building for Boys, and 1 Building for Girls)

\begin{tabular}{|c|c|c|c|c|}
\hline No & $\begin{array}{l}\text { Activity } \\
\text { Program }\end{array}$ & Advisors & $\begin{array}{l}\text { Activity } \\
\text { Volume }\end{array}$ & Schedule \\
\hline 1 & $\begin{array}{l}\text { Character and } \\
\text { Religious } \\
\text { Education }\end{array}$ & $\begin{array}{l}\text { a) Murobbi/Main Advisor } \\
2 \text { PAI Lecturer } \\
\text { b) Musyrif/Co-Advisor } \\
\text { \# } 10 \text { students who are active in } \\
\text { Religious organization }\end{array}$ & $\begin{array}{l}\text { 2-3 hours } \\
\text { a day }\end{array}$ & Thursday \\
\hline 2 & $\begin{array}{l}\text { Entrepreneurship } \\
\text { and Competence } \\
\text { Developing }\end{array}$ & $\begin{array}{l}\text { a)Murobbi/Main Advisor } \\
2 \quad \text { FE Lecturers who have } \\
\text { entrepreneurship experience. } \\
\text { b) Musyrif/Co-Advisor } \\
\text { \# } 10 \text { students who have } \\
\text { entrepreneurship experience. }\end{array}$ & $\begin{array}{l}\text { 2-3 hours } \\
\text { a day }\end{array}$ & Friday \\
\hline 3 & $\begin{array}{l}\text { Leadership } \\
\text { Development }\end{array}$ & $\begin{array}{l}\text { a) Murobbi/Main Advisor } \\
2 \text { Lecturer who have organization } \\
\text { experience } \\
\text { b) Musyrif/Co-advisor } \\
\text { \# } 10 \text { students who are active in } \\
\text { organization }\end{array}$ & $\begin{array}{l}2-3 \text { hours } \\
\text { a day }\end{array}$ & Monday \\
\hline 4 & $\begin{array}{l}\text { Foreign } \\
\text { Language } \\
\text { development } \\
\text { (English) }\end{array}$ & $\begin{array}{l}\text { a) Murobbi/Main Advisor, } \\
2 \text { English Lecturers } \\
\text { b)Musyrif/Co-Advisor } \\
\text { \# } 10 \text { English students. }\end{array}$ & $\begin{array}{l}2-3 \text { hours } \\
\text { a day }\end{array}$ & Tuesday \\
\hline 5 & Sport Education & $\begin{array}{l}\text { a)Murobbi/Main Advisor, } \\
2 \text { FIK Lecturers } \\
\text { b)Musyrif/Co-Advisor } \\
\text { \# } 10 \text { experienced students }\end{array}$ & $\begin{array}{l}2-3 \\
\text { students } \\
\text { a day }\end{array}$ & Wednesday \\
\hline
\end{tabular}

\# Every Musyrif/Co-Advisor are 5 boy students and 5 girls, 5 musyrif advise 5 boys as santri, 5 musyrifah advise 5 girls as santri.
Here are the recruitment mechanisms: For murobbi/main advisors (10 lecturers), they are taken by the recommendations from many sources. For musyrif/Co-Advisors (50 students), they are 
taken through the registration process and selection. For Bidikmisi students are through leader's policy for Bidikmisi students obligate to stay at campus boarding house a year. While for non Bidikmisi students are through registration process and selection as long as the building capacity/rooms are available.

\section{Curriculum Chart/Islamic Boarding} Campus Activities

Slogan/Motto : Growing With

Character

Program Theme : Character building education Based on Islamic boarding campus House

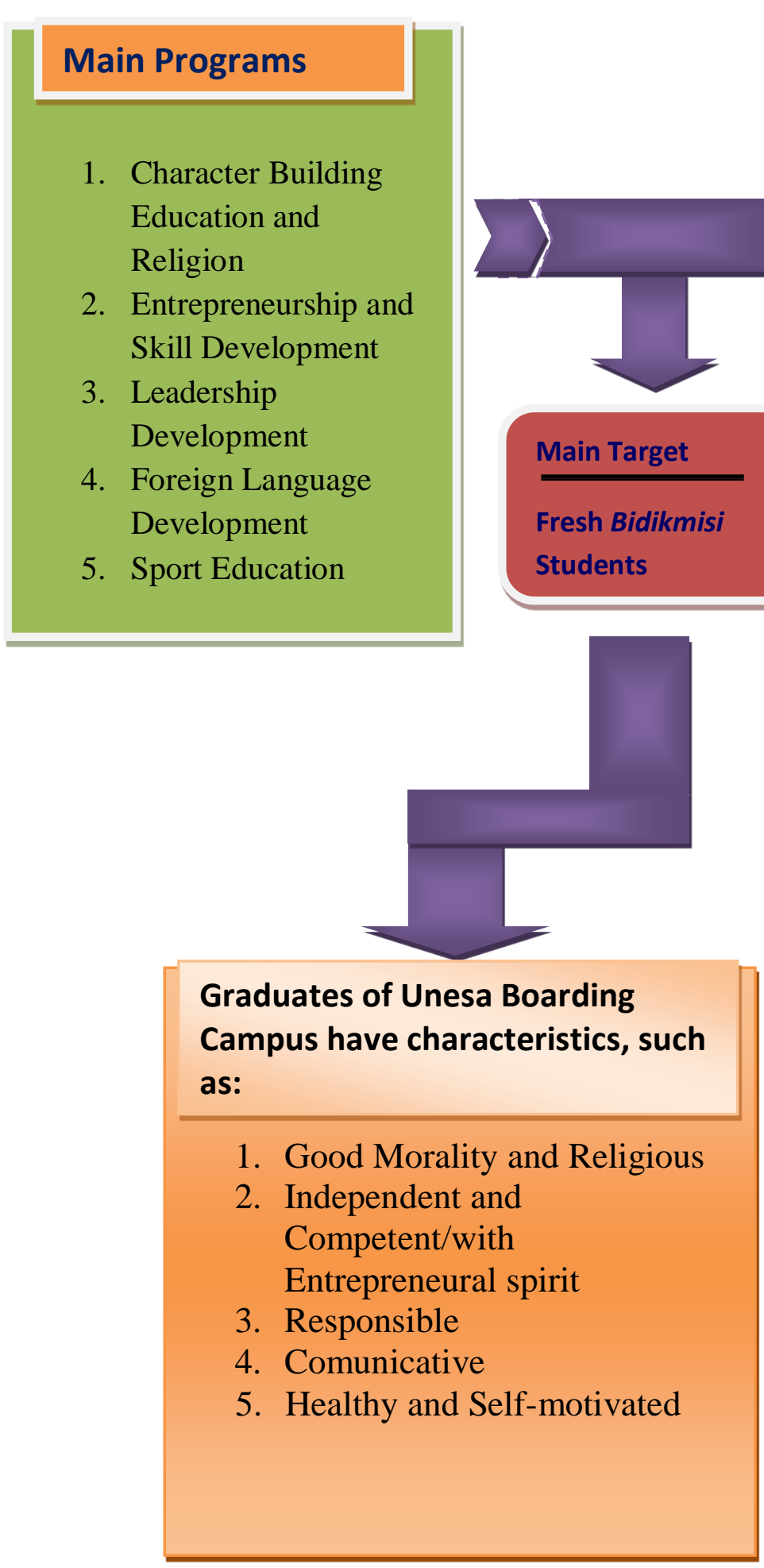

Murobbi (Advisor)

Musyrif/ah (Co-Advisor)

1. 2 PAI Lecturers as murobbi (Advisor)

10 Students as musyrif/ah (CoAdvisor)

2. 2 FE Lecturers as murobbi (Advisor)

10 Students as musyrif/ah (CoAdvisor)

3. 2 Organization-base Lecturers as murobbi (Advisor)

10 Senate students/organization students as musyrif/ah (CoAdvisor)

4. 2 English Lecturers as murobbi (Advisor)

10 Students as musyrif/ah (CoAdvisor)

5. 2 FIK Lecturers as murobbi (Advisor)

10 Students as musyrif/ah (CoAdvisor) 


\section{CONCLUSION AND SUGGESTION}

\section{CONCLUSION}

1. The implementation of character building education in Unesa and UIN Malang has its own characteristic and uniqueness, interesting and effective variations in student character building, such as monolithic model, integrated model, outside teaching class model, and combination model

2. The draft model of character building education based on Islamic boarding campus has been designed; and it is expected in later time can be implemented in public campuses, including Unesa.

\section{SUGGESTION}

For Unesa which has facility like boarding campus (1 building has been functioning well and 1 remains on progress of building) should more maximize the existed facilities by designing programs which is able to implement educative and character values to students effectively through Islamic Boarding Campus design. This is line with the commitment of the motto of Unesa "Growing with character".

\section{REFERENCES}

[1] Aqib, Zainal. 2011. Pendidikan Karakter: Membangun perilaku positif anak bangsa. Bandung: Yrama Widya.

[2] Darma, Budi. 2011. Kata Pengantar. Dalam Sirikit Syah dan Martadi (eds.). Bunga Rampai Pendidikan Karakter: Strategi mendidik generasi masa depan. Surabaya: Unesa University Press.

[3] Huda, Miftahul, 2006. Pesantren Perguruan Tinggi Berbasis Kultural. Malang : Lemlit UIN Malang.
[4] Husen, Achmad, dkk. 2010. Model Pendidikan Karakter Bangsa. Jakarta : Universitas Negeri Jakarta.

[5] Latif, Yudi. 2014. Strategi Kebudayaan Hilang ; Pendidikan Butuh Arah yang Jelas. Jakarta : Kompas 17 Juni 2014.

[6] Samani, Muchlas dan Hariyanto. 2011. Konsep dan Model Pendidikan Karakter. Bandung : Remaja Rosdakarya.

[7] Samani, Muchlas. 2012. Profesionalisasi Pendidikan. Surabaya: Unesa University Press.

[8] Samani, Muchlas. 2011. Membangun Karakter, Mengukir Masa Depan. Dalam Sirikit Syah dan Martadi (eds.). Bunga Rampai Pendidikan Karakter: Strategi mendidik generasi masa depan. Surabaya: Unesa University Press.

[9] Syah, Sirikit dan Martadi (eds.). 2011a. Bunga Rampai Pendidikan Karakter: Strategi mendidik generasi masa depan. Surabaya: Unesa University Press.

[10]

2011b. Rekonstruksi Pendidikan: Kumpulan Pemikiran tentang perlunya merekonstruksi pendidikan di Indonesia. Surabaya: Unesa University Press.

[11] Syah, Sirikit dan Suyatno. 2012. Jejak Budaya dalam Karakter Siswa Indonesia. Surabaya: Unesa Universiy Press.

[12] Setiawan, Slamet. 2012. The fading away of Javanese language among children: the representation of declining local cultures in Asia. Prosiding Seminar Internasional tentang Budaya Asia Tenggara. Tema: South East Asian Culture: Trends and Challenges. Judul:.16 Juli 2012.

[13] Stevenson, Nancy. 2006. Young Person's Character building education Handbook. Indianapolis: JIST Publishing. 
[14] Sutarto, Ayu. 2011. Lokal sebagai Penguatan Karakter dan Pekerti Bangsa. Dalam Sirikit Syah dan Martadi (eds.). Bunga Rampai Pendidikan Karakter: Strategi mendidik generasi masa depan. Surabaya: Unesa University Press.

[15] Warsono,dkk. 2010. Model Pendidikan Karakter di Unesa. Surabaya : University Press.

[16] Yani, Muhammad Turhan. 2007. Pendidikan Berbasis Moral di Sekolah, Keluarga, dan Masyarakat. Unesa. Jurnal Pelangi Ilmu.

[17] -------------------------, 2012. Agama Sebagai Basis Utama Pendidikan Karakter. Balai Diklat Keagamaan Kota Surabaya. Jurnal Inovasi. 